\title{
Optimization of enzymatic hydrolysis condition of snakehead (Channa striata) protein hydrolysate based on yield and antioxidant activity
}

\author{
Rasimi, N.A.S.M., Ishak, N.H., Mannur, I.S. and *Sarbon, N.M. \\ Faculty of Fisheries and Food Science, Universiti Malaysia Terengganu, 21030 Kuala Nerus, Terengganu, \\ Malaysia
}

Article history:

Received: 21 May 2020

Received in revised form: 15 June 2020

Accepted: 4 July 2020

Available Online: 13 August 2020

Keywords:

Sankehead,

Enzymatic hydrolysis,

Optimization,

RSM,

Yield,

Antioxidant activity

DOI:

https://doi.org/10.26656/fr.2017.4(6).237

\section{Introduction}

Haruan, the local name of snakehead (Channa striata) is a genus of Channidae family, is an important freshwater in Malaysia (Ghassem et al., 2014). Traditionally, snakehead has a tremendous market value due to their high quality of protein, low fat, less intramuscular spines and medicinal qualities (Haniffa and Marimuthu, 2004). According to Ghassem et al. (2014), the proximate composition and amino acid content revealed that snakehead had a higher amount of protein and essential amino acids such as glutamic acid, aspartic acid and lysine in comparison with other freshwater fishes in Malaysia. Several food protein hydrolysates have been found to exhibit antioxidant activity. A number of antioxidative peptides, usually composed of 5-16 amino acid residues, have been isolated from soybean hydrolysate and included hydrophobic amino acids (Val or Leu) at the N-terminus, and Pro, His or Tyr in sequences (Sarbon et al., 2018). Thus, snakehead protein hydrolysate is believed to have beneficial antioxidant properties in addition to its use as a nutritional food.
Enzymatic hydrolysis is one method used to produce fish protein hydrolysate. The process is influenced by several factors such as temperature, $\mathrm{pH}$, time and enzyme to substrate concentration. Enzymatic hydrolysis involves enzymes that facilitate the cleavage of molecular bonds in molecules with watery elements. Several protein hydrolysates are able to be produced using various fish muscle proteins from several fish species such as eel (Monopterus sp.) (Halim and Sarbon, 2017) and round scad (Decapterus maruadsi) (Thiansilakul et al., 2007). A variety of enzymes are employed in the preparation of protein hydrolysates. These include alcalase, bromelain, flavourzyme, neutrase, pepsine, trypsine and papain (Razali et al., 2015). Alcalase, which is close to neutral with an optimal $\mathrm{pH}$ reaction of 7 and 9 , has been reported to be the most efficient hydrolysis (Ishak and Sarbon, 2017). Alcalase can solubilize fish protein at optimized temperatures ranging from 50 to $70^{\circ} \mathrm{C}$, and within an optimal pH range of 8-10 (See et al., 2011).

In order to obtain the optimum hydrolysis conditions with the targeted responses, such as yield and antioxidant activity, optimization should be considered. 
Optimization is a modern statistically derived experimental design that commonly used in analytic chemistry to find the best alternative from a specified set of alternatives (See et al., 2011). The response surface methodology (RSM) was the most selected method by researchers in the study of fish hydrolysates such as eel (Monopterus Sp.) (Halim and Sarbon, 2017), skipjack tuna (Katsuwonus pelamis) (Herpendi et al., 2013) and cockle (Anadara granosa) (Haslaniza et al., 2013). The optimization of enzymatic hydrolysis conditions for protein hydrolysate production was controlled by four variables; namely, temperature, $\mathrm{pH}$, time and enzyme to substrate concentration (See et al., 2011).

Antioxidants include any substance with the ability to delay or inhibit oxidation are widely used in food industries (Chalamaiah et al., 2012). Umayaparvathi et al. (2014) stated that some synthetic antioxidants, such as butylated hydroxytoluene (BHT), butylated hydroxyanisole (BHA), and propyl gallate are commonly added to retard lipid oxidation. However, due to potential health risks from synthetic antioxidants, the search for natural antioxidants has become a focus of considerable interest (Chalamaiah et al., 2012). Several studies from fish sources have shown potential antioxidant effects, such as eel (Halim and Sarbon, 2017) and shortfin scad (Kang et al., 2018). Hence, the demand for natural and safe antioxidant from snakehead must be explored. This natural antioxidant can be used by incorporation in the food system or as a food supplement.

The objectives of the study were to determine the chemical composition of snakehead; optimize the enzymatic hydrolysis condition of snakehead protein hydrolysate in terms of temperature, enzyme/substrate ratio, time and $\mathrm{pH}$ on yield and antioxidant activity as responses via Response Surface Methodology (RSM); and determine the antioxidant activity of snakehead protein hydrolysate produced using optimized condition.

\section{Material and methods}

\subsection{Materials}

Snakehead was purchased from local suppliers in Kuala Terengganu, Terengganu. Alcalase 2.4L FG, a bacterial endoprotease produced by Bacillus licheniformis was obtained from Novozymes. All chemical used in this study were of analytical grade.

\subsection{Sample preparation}

The snakehead was brought alive to the laboratory. The flesh were separated manually, washed with excessive tap water and minced by using a Waring blender (model HGB2WTS3, Connecticut, USA) and stored at $-40^{\circ} \mathrm{C}$ in polyethylene plastic bag before being subjected to further analysis.

\subsection{Chemical composition analysis of snakehead protein}

The chemical compositions (moisture, crude protein, crude fat and ash content) of the snakehead flesh were carried out according to the method of AOAC (2002). Crude protein measurements were conducted with the Kjeldahl method via the Kjeltec protein analyzer (FossTecator AB, Sweden).

\subsection{Preparation of snakehead protein hydrolysate (SPH)}

Snakehead protein hydrolysate (SPH) was prepared according to the method as described by Hamid et al. (2015) with a slight modification. About $16.5 \mathrm{~g}$ of snakehead minced flesh was mixed in $16.5 \mathrm{~g}$ of distilled water and homogenized in a blender. The mixtures were then placed in the water bath and stirred until achieving the required temperature. Once the temperature has been stabilized, the $\mathrm{pH}$ was kept constant by adding $0.1 \mathrm{~N}$ $\mathrm{NaOH}$ and the time of hydrolysis process were recorded. Alcalase was added and stirred for $5 \mathrm{~min}$ of homogenization. After the slurry reached the specified hydrolysis time, the slurry was inactivated by heating it at $90^{\circ} \mathrm{C}$ for 10 mins. The resultant slurry was centrifuged at $5000 \mathrm{rpm}$ at $4^{\circ} \mathrm{C}$ for 20 mins. The supernatant was collected and freeze-dried. The freeze-dried hydrolysates were used for further analysis.

\subsection{Yield and DPPH radical scavenging activity for optimization of snakehead protein hydrolysate (SPH)}

The yield of snakehead protein hydrolysate (SPH) was calculated as follows:

Yield (\%) = Dry weight of hydrolysate (g) / Wet weight of flesh (g) X 100

DPPH radical scavenging activity was conducted following Hamid et al. (2015). Approximately $500 \mu \mathrm{L}$ of the sample was mixed with $500 \mu \mathrm{L}$ of ethanol and 125 $\mu \mathrm{L}(0.02 \%, \mathrm{w} / \mathrm{v})$ of $\mathrm{DPPH}$ in $99.5 \%$ ethanol. The mixture was shaken vigorously by using vortex and incubated in the dark. After 60 mins, absorbance was measured at $517 \mathrm{~nm}$ using a UV-Vis spectrophotometer. DPPH radical scavenging activity was calculated as follows:

$$
\operatorname{DPPH}(\%)=\left[\left(\mathrm{A}_{\text {control }}-\mathrm{A}_{\text {sample }}\right) / \mathrm{A}_{\text {control }}\right] \times 100
$$

Where $\mathrm{A}_{\text {control }}$ was the absorbance of control reaction and $\mathrm{A}_{\text {sample }}$ was the absorbance of hydrolysate. BHT was used as a positive control. A lower absorbance of the reaction mixture indicated a higher DPPH radical scavenging activity. The tests were conducted in triplicate. 
2.6 Optimization of enzymatic hydrolysis conditions of snakehead protein hydrolysate (SPH)

Response surface methodology (RSM) DesignExpert 6.0.10 software (Stat-Ease 2003) was used to predict the optimum hydrolysis condition for the production of snakehead protein hydrolysate (SPH) using Alcalase ${ }^{\circledR}$ enzyme. Four different independent variables, namely temperature $\left(45,55,65^{\circ} \mathrm{C}\right)$, time $(60,120,180$ mins), enzyme to substrate concentration $(1,2,3 \%, \mathrm{v} / \mathrm{w})$, and $\mathrm{pH}(8,9,10)$ were used during the hydrolysis process. 30 hydrolysis trials at three equidistant levels (1,0 and +1 ) were randomly run per Central Composite Design (CCD). The responses measured from the RSM included yield (\%) and DPPH antioxidant activity (\%) (Table 1). Validation of DPPH radical scavenging activity for the optimized snakehead protein was also conducted.
2.7 Antioxidant activity of snakehead protein hydrolysate (SPH)

\subsubsection{Chelating effects on ferrous ion}

The chelation of ferrous ions by snakehead protein hydrolysate was determined by the method described by Hamid et al. (2015) with some modification. $1.6 \mathrm{~mL}$ of distilled water and $50 \mu \mathrm{L}$ of $2 \mathrm{mM} \mathrm{FeCl}_{2}$ were added to the sample at concentration $1 \mathrm{mg} / \mathrm{mL}$. After $15 \mathrm{mins}$, $0.1 \mathrm{~mL} 5 \mathrm{mM}$ ferrozine was added. The mixture was vigorously shaken and then left to stand at room temperature for 10 mins. BHT was used as a positive control. Spectrophotometric absorbance was measured at $562 \mathrm{~nm}$ and the metal chelating activity of SPH was calculated as follows:

Metal chelating effect $(\%)=\left[\left(\mathrm{Abs}_{1}-\mathrm{Abs}_{2}\right) / \mathrm{Abs}_{1}\right] \times 100$

Where $\mathrm{Abs}_{1}$ is the absorbance of the control and $\mathrm{Abs}_{2}$ is the observed absorbance for the sample snakehead protein hydrolysate. The tests were conducted in triplicate.

Table 1. Actual level of independent variables used in optimizing the hydrolysis conditions using Alcalase ${ }^{\circledR}$ enzyme and its observed values for yield and antioxidant activity

\begin{tabular}{|c|c|c|c|c|c|c|}
\hline Std & Run & Time (min) & Temperature $\left({ }^{\circ} \mathrm{C}\right)$ & $\mathrm{pH}$ & Enzyme (\%) & Yield (\%) DPPH (\%) \\
\hline 6 & 1 & 1 & 1 & -1 & 1 & \\
\hline 16 & 2 & 1 & 1 & 1 & 1 & \\
\hline 8 & 3 & 1 & 1 & 1 & 1 & \\
\hline 2 & 4 & 1 & 1 & -1 & -1 & \\
\hline 1 & 5 & 1 & -1 & -1 & -1 & \\
\hline 14 & 6 & 1 & 1 & -1 & 1 & \\
\hline 9 & 7 & 1 & -1 & -1 & -1 & \\
\hline 12 & 8 & 1 & 1 & 1 & -1 & \\
\hline 4 & 9 & 1 & 1 & 1 & -1 & \\
\hline 5 & 10 & 1 & -1 & -1 & 1 & \\
\hline 15 & 11 & 1 & -1 & 1 & 1 & \\
\hline 17 & 12 & 1 & 0 & 0 & 0 & \\
\hline 19 & 13 & 1 & 0 & 0 & 0 & \\
\hline 3 & 14 & 1 & -1 & 1 & -1 & \\
\hline 7 & 15 & 1 & -1 & 1 & 1 & \\
\hline 11 & 16 & 1 & -1 & 1 & -1 & \\
\hline 18 & 17 & 1 & 0 & 0 & 0 & \\
\hline 10 & 18 & 1 & 1 & -1 & -1 & \\
\hline 20 & 19 & 1 & 0 & 0 & 0 & \\
\hline 13 & 20 & 1 & -1 & -1 & 1 & \\
\hline 30 & 21 & -1 & 0 & 0 & 0 & \\
\hline 24 & 22 & -1 & 0 & 1 & 0 & \\
\hline 27 & 23 & -1 & 0 & 0 & 0 & \\
\hline 29 & 24 & -1 & 0 & 0 & 0 & \\
\hline 23 & 25 & -1 & 0 & -1 & 0 & \\
\hline 28 & 26 & -1 & 0 & 0 & 0 & \\
\hline 22 & 27 & -1 & 1 & 0 & 0 & \\
\hline 26 & 28 & -1 & 0 & 0 & 1 & \\
\hline 25 & 29 & -1 & 0 & 0 & -1 & \\
\hline 21 & 30 & -1 & -1 & 0 & 0 & \\
\hline
\end{tabular}




\subsubsection{Hydroxyl radical scavenging activity (HRSA)}

The scavenging activity for hydroxyl radicals was measured by the Fenton Reaction according to the method as described by Hamid et al. (2015). The reaction mixture contained $60 \mu \mathrm{l}$ of $1.0 \mathrm{mM} \mathrm{FeCl} 3,90$ $\mu \mathrm{L}$ of $1 \mathrm{mM} 1,10$-phenanthroline, $2.4 \mathrm{~mL}$ of $0.2 \mathrm{M}$ phosphate buffer ( $\mathrm{pH} 7.8), 150 \mu \mathrm{L}$ of $0.17 \mathrm{M} \mathrm{H}_{2} \mathrm{O}_{2}$ and $1.5 \mathrm{~mL}$ of snakehead protein hydrolysate $(\mathrm{SPH})$ at concentration of $1 \mathrm{mg} / \mathrm{mL}$. The reaction was started with the addition of $\mathrm{H}_{2} \mathrm{O}_{2}$. BHT was used as a positive control. Absorbance at $560 \mathrm{~nm}$ was measured with a spectrophotometer after incubation at room temperature for $5 \mathrm{~min}$. The hydroxyl radical scavenging activity was calculated as follows:

$$
\text { Inhibition } \left.(\%)=\left(\mathrm{A}_{0}-\mathrm{A}_{1}\right) / \mathrm{A}_{0} \times 100\right)
$$

Where $\mathrm{A}_{0}$ is the absorbance of the control (blank) and $\mathrm{A}_{1}$ is the absorbance in the presence of the sample. The values were presented as the result of triplicate analyses.

\subsubsection{DPPH radical scavenging activity}

The method of Hamid et al. (2015) was used to analyse the DPPH radical- scavenging activity with some modification. Approximately $500 \mu \mathrm{L}$ of the sample was mixed with $500 \mu \mathrm{L}$ of ethanol and $125 \mu \mathrm{L}(0.02 \%$, w $/ v)$ of DPPH in $99.5 \%$ ethanol. The mixtures were shaken vigorously using a vortex and incubated in the dark. After 60 mins, absorbance was measured at $517 \mathrm{~nm}$ using Uv-Vis spectrophotometer. The DPPH radical scavenging activity was calculated as follows:

$$
\operatorname{DPPH}(\%)=\left[\left(\mathrm{A}_{\text {control }}-\mathrm{A}_{\text {sample }}\right) / \mathrm{A}_{\text {control }}\right] \times 100
$$

Where $A_{\text {blank }}$ was the absorbance of control reaction and $\mathrm{A}_{\text {sample }}$ was the absorbance of hydrolysate. BHT was used as a positive control. Lower absorbance of the reaction mixture indicates a higher DPPH radical-scavenging activity. The test was conducted in triplicate.

\subsection{Statistical analysis}

Optimization data was analysed using Design Expert 6.0.10 software (Stat-Ease 2003). Results were expressed as a mean ( $\pm \mathrm{SD})$ for each analysis. Comparative statistical analysis between means with ANOVA was calculated with the Minitab 14.0 to assess significant differences $(\mathrm{p}<0.05)$.

\section{Results and discussion}

\subsection{Chemical composition of snakehead muscle}

The moisture content, crude protein, crude fat and ash content of snakehead flesh obtained were $80.43 \%$, $15.44 \%, 0.53 \%$ and $0.72 \%$, respectively. The moisture content values are in agreement with results obtained by
Zuraini et al. (2006) and Ahmed et al. (2012), reported moisture levels of $83.5 \%$ and $82.66 \%$, respectively. While, the snakehead flesh crude protein was lower than eel flesh (16.88\%) reported by Halim and Sarbon, (2017). The higher moisture content was due to the main constituent of fish protein being water, while the levels of protein content mean that snakehead flesh has potential as a protein supplement for human nutrition (Chalamaiah et al., 2012). Moreover, the fat and ash levels in snakehead flesh are lower than those of eel protein as measured by Halim and Sarbon (2017). The fat content in fish varies according to the season, species, and geographical variation. Age variation and sexual maturity in the same species also contribute to the significant differences in the total lipid contents (Piggott and Tucker, 1990). The variance in ash content might due to the different concentrations of fatty acids and minerals found in snakehead flesh.

3.2 Optimization of enzymatic hydrolysis condition on yield and antioxidant activity by response surface methodology (RSM)

Response Surface Methodology (RSM) was used to optimize the enzymatic hydrolysis conditions for the preparation of snakehead protein hydrolysate (SPH). Overall, 30 runs of hydrolysis experiments were carried out based on Central Composite Design with facecentred (six central points) with 4 independent factors, namely time ( $\min , \mathrm{A})$, temperature $\left({ }^{\circ} \mathrm{C}, \mathrm{B}\right), \mathrm{pH}(\mathrm{C})$ and enzyme-substrate concentration $(\%, \mathrm{D})$ on two responses; yield (\%) and antioxidant activity (\%) (Table 2 ). The yield of freeze-dried SPH obtained from 30 experimental runs ranged from $8.86 \%$ to $10.66 \%$, which was lower than reported from the yield of typical fish hydrolysate (10-15\%) (Quaglia and Orban, 1990). The yield of hydrolysate was influenced by the percentage of solubilised protein which depends on the amount of lipids in the raw material. Raw material containing the lowest amount of lipids gave the highest percentage of solubilised protein which leads to the increasing of yield (Slizyte et al., 2005). The higher yield obtained from the optimized conditions of enzymatic hydrolysis indicates good hydrolysate reproducibility while reducing costs (Maache-Rezzoug et al., 2011).

Meanwhile, the DPPH antioxidant activity values on optimized hydrolysis condition ranged from $18.76 \%$ to $27.74 \%$ which was lower than the DPPH antioxidant of the optimized hydrolysis condition of eel protein (85.32\% to $90.85 \%)$ (Halim and Sarbon, 2017). These differences in antioxidant activity of fish hydrolysates might be due to the differences in fish species, fish parts, types of enzymes used and hydrolysis conditions applied, which correspond to the hydrolysis parameters used. The 
Table 2. Actual level of independent variables used in optimizing the hydrolysis conditions using Alcalase ${ }^{\circledR}$ enzyme and its observed values for yield and antioxidant activity

\begin{tabular}{|c|c|c|c|c|c|c|c|}
\hline Std & Run & A: Time $(\min )$ & B: Temperature $\left({ }^{\circ} \mathrm{C}\right)$ & $\mathrm{C}: \mathrm{pH}$ & D:Enzyme/subtrate (\%) & Yield (\%) & DPPH (\%) \\
\hline 6 & 1 & 1 & 1 & -1 & 1 & 7.11 & 20.21 \\
\hline 16 & 2 & 1 & 1 & 1 & 1 & 10.55 & 22.06 \\
\hline 8 & 3 & 1 & 1 & 1 & 1 & 6.96 & 24.31 \\
\hline 2 & 4 & 1 & 1 & -1 & -1 & 8.47 & 18.49 \\
\hline 1 & 5 & 1 & -1 & -1 & -1 & 5.24 & 19.55 \\
\hline 14 & 6 & 1 & 1 & -1 & 1 & 14.47 & 25.63 \\
\hline 9 & 7 & 1 & -1 & -1 & -1 & 5.84 & 16.64 \\
\hline 12 & 8 & 1 & 1 & 1 & -1 & 5.85 & 12.42 \\
\hline 4 & 9 & 1 & 1 & 1 & -1 & 6.93 & 23.12 \\
\hline 5 & 10 & 1 & -1 & -1 & 1 & 5.98 & 26.02 \\
\hline 15 & 11 & 1 & -1 & 1 & 1 & 7.62 & 28.27 \\
\hline 17 & 12 & 1 & 0 & 0 & 0 & 9.08 & 24.57 \\
\hline 19 & 13 & 1 & 0 & 0 & 0 & 9.86 & 20.61 \\
\hline 3 & 14 & 1 & -1 & 1 & -1 & 3.41 & 19.42 \\
\hline 7 & 15 & 1 & -1 & 1 & 1 & 5.23 & 22.85 \\
\hline 11 & 16 & 1 & -1 & 1 & -1 & 7.97 & 23.65 \\
\hline 18 & 17 & 1 & 0 & 0 & 0 & 9.66 & 21.53 \\
\hline 10 & 18 & 1 & 1 & -1 & -1 & 9.32 & 31.84 \\
\hline 20 & 19 & 1 & 0 & 0 & 0 & 8.86 & 18.76 \\
\hline 13 & 20 & 1 & -1 & -1 & 1 & 7.24 & 26.02 \\
\hline 30 & 21 & -1 & 0 & 0 & 0 & 10.66 & 27.74 \\
\hline 24 & 22 & -1 & 0 & 1 & 0 & 7.65 & 22.06 \\
\hline 27 & 23 & -1 & 0 & 0 & 0 & 5.98 & 20.21 \\
\hline 29 & 24 & -1 & 0 & 0 & 0 & 10.47 & 21.8 \\
\hline 23 & 25 & -1 & 0 & -1 & 0 & 8.2 & 20.21 \\
\hline 28 & 26 & -1 & 0 & 0 & 0 & 10.69 & 7.79 \\
\hline 22 & 27 & -1 & 1 & 0 & 0 & 7.53 & 25.1 \\
\hline 26 & 28 & -1 & 0 & 0 & 1 & 10.58 & 15.98 \\
\hline 25 & 29 & -1 & 0 & 0 & -1 & 7.2 & 20.21 \\
\hline 21 & 30 & -1 & -1 & 0 & 0 & 8.14 & 52.18 \\
\hline
\end{tabular}

antioxidant activity of SPH may be contributed by the exposure on hydrophobic peptides of snakehead flesh protein during hydrolysis by Alcalase ${ }^{\circledR}$ enzyme. This finding as supported with the study done by Sarbon et al. (2018), who found that a high amount of hydrophobic amino acids (Gly, Ala, Pro and Tyr) detected in the Alcalase ${ }^{\circledR}$ enzyme hydrolysed chicken skin gelatin, contributed to the high antioxidative activity.

\subsection{Analysis for yield of snakehead protein hydrolysate (SPH)}

3.3.1 Model summary statistics for a yield of snakehead protein hydrolysate (SPH)

In this experiment, the linear model was the model summary suggested for the yield of SPH. The linear model suggested for the SPH yield was the contrast with the previous studies that reported on the optimization of Golden apple snail (GAS) (Hamid et al., 2015), who found that the predicted model for GAS protein hydrolysate was quadratic. The difference in the prediction model for SPH yield may be due to the differences in the raw materials, protein content and hydrolysis conditions applied.
3.4 Analysis of variance (ANOVA) for yield of snakehead protein hydrolysate (SPH)

The analysis of variance (ANOVA) for the Response Surface Linear Model for the yield of SPH after model reduction is shown in Table 3. The "Lack of Fit F-value" of this model was 18.30 indicates there is only $0.60 \%$ chance that a "Lack of Fit F-value" this large could occur due to noise. Hence, the model fit experimental data with a determination coefficient of $\left(\mathrm{R}^{2}=0.5403\right)(\mathrm{p}<0.05)$ (Table 3 ). $\mathrm{R}^{2}$ should be more than 0.80 to obtain a good fit for the model and thus explain data variation (Halim and Sarbon, 2017). Adequate precision was used to measure the signal to noise ratio and a ratio greater than 4 was desirable (Canettieri et al., 2007). For this model, the "Adequate Precision" ratio was 10.688 , which was an adequate signal-to-noise ratio. Therefore, this model proved to be powerful for navigating the design space. Meanwhile, the p-value $(<0.05)$ also implies that the model's terms were significant. In this case, time (A), $\mathrm{pH}$ (C) and enzyme to substrate concentration (D) had a significant effect $(\mathrm{p}<0.05)$ on SPH yield. 
Table 3. Analysis of variance (ANOVA) for all model terms and model interaction on yield of snakehead protein hydrolysate

\begin{tabular}{ccccccc}
\hline Source & Sum of Squares & DF & Mean Square & F Value & Prob $>$ F & \\
\hline Model & 74.63 & 4 & 18.66 & 7.05 & 0.0007 & significant \\
A & 23.39 & 1 & 23.39 & 8.84 & 0.0066 & \\
B & 5.23 & 1 & 5.23 & 1.98 & 0.1726 & \\
C & 13.36 & 1 & 13.36 & 5.05 & 0.0341 & \\
D & 32.64 & 1 & 32.64 & 12.34 & 0.0018 & \\
& 63.49 & 24 & 2.65 & & & \\
Residual & 62.81 & 20 & 3.14 & 18.3 & $\mathbf{0 . 0 0 6 0}$ & \\
Lack of Fit & 0.69 & 4 & 0.17 & & & \\
Pure Error & 143.86 & 29 & & & &
\end{tabular}

Cor Total

R-squared $\quad 0.5403$

significant

3.5 Response surface plots and the effects of factors for the yield of snakehead protein hydrolysate (SPH)

According to the model regression analysis, the best explanatory model equation was given as follows:

Yield of snakehead protein hydrolysate $(\mathrm{SPH})=+8.25+$ $1.14 \mathrm{~A}-0.54 \mathrm{~B}+0.86 \mathrm{C}+1.35 \mathrm{D}$.

A 3D response surface were graphical representations of the regression equation. Figure 1 (a) showed the response surface plot for hydrolysate yield as a function of time and $\mathrm{pH}$. Increased hydrolysis time resulted in higher yields $(9.48 \%)$, with the highest hydrolysate yield obtained at $180 \mathrm{~min}$, a result that concurred with a study by Hamid et al. (2015). This result explains that the breakdown of the peptide continuously occurred with the increasing time. Hence, it can be concluded that a longer enzymatic hydrolysis period yielded higher amounts of the end product. In terms of $\mathrm{pH}$, increased $\mathrm{pH}$ levels produced higher $\mathrm{SPH}$ yield (9.48\%). According to See et al. (2011), Alcalase ${ }^{\circledR}$ enzyme is able to solubilize fish protein at $\mathrm{pH}$ range from 8 to 10. Based on the graph, it can be seen that the breakdown of SPH into smaller peptides actively occurred from $\mathrm{pH} 8$ to 10 . However, the highest yield obtained in this study was in a $\mathrm{pH}$ range of 9.0 to 10.0 .

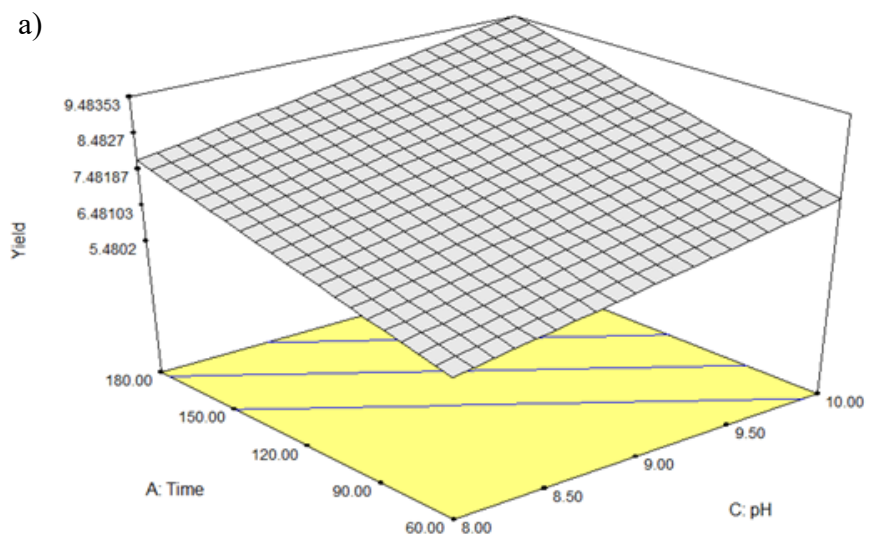

3.6 Analysis of antioxidant activity of snakehead protein hydrolysate (SPH)

3.6.1 Model summary statistics and analysis of variance (ANOVA) for antioxidant activity of snakehead protein hydrolysate (SPH)

The model summary for the antioxidant of SPH was a quadratic. The same model was reported in a study by Halim and Sarbon (2017) on the enzymatic hydrolysis of eel muscle. The resulting ANOVA table for the reduced quadratic model for antioxidant activity is shown in Table 4. The Model F-value of 2.73 implies the model is significant. There is only a $3.13 \%$ chance that a "Model F-value" this large could occur due to noise. While the "Lack of Fit F-value" of this model was 4.81 implies the lack of fit is not significant. There is only $6.99 \%$ chance that a "Lack of Fit F-value" this large could occur due to noise. The coefficient of variation $\left(\mathrm{R}^{2}=0.5639\right)$ indicates that $43.61 \%$ of the total variations are not explained by the model. Meanwhile, the adequate precision ratio of the model was 7.326, indicating adequate signals. Therefore, this model could be used to navigate the design space for the determination of hydrolysis conditions of SPH on antioxidant activity for any combination of independent variables within the range studied. Furthermore, values of "Prob $>$ F" less than 0.05 indicate that the model terms are significant. In

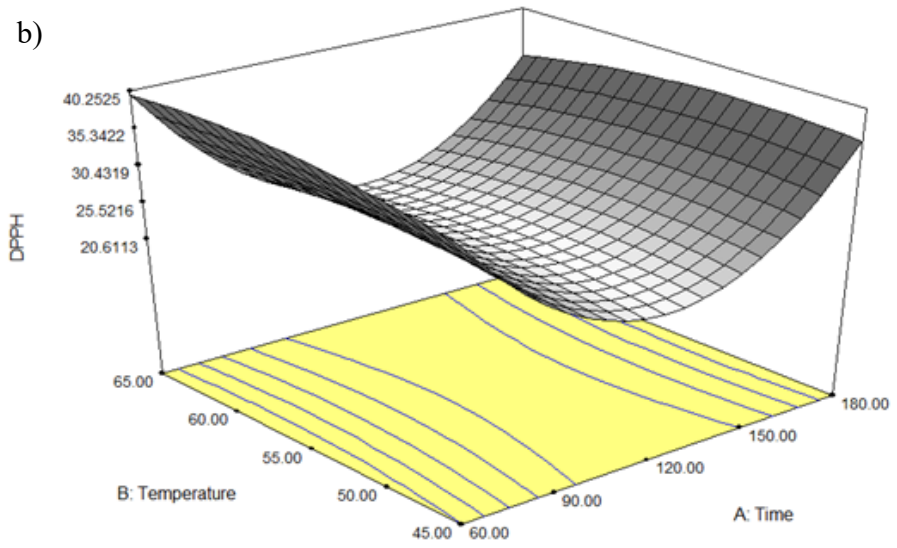

Figure 1. Response surface plot for a) yield (\%) as a function of time and pH, b) DPPH antioxidant activity (\%) as a function of temperature and time 
Table 4. Analysis of variance (ANOVA) for all model terms and model interaction on antioxidant activity of snakehead protein hydrolysate

\begin{tabular}{ccccccc}
\hline Source & Sum of Squares & DF & Mean Square & F Value & Prob $>$ F & \\
\hline Model & 869.22 & 9 & 96.58 & 2.73 & $\mathbf{0 . 0 3 1 3}$ & significant \\
A & 54.85 & 1 & 54.85 & 1.55 & 0.2282 & \\
C & 37.58 & 1 & 37.58 & 1.06 & 0.3156 & \\
A $^{2}$ & 641.75 & 1 & 641.75 & 18.14 & 0.0004 & \\
B $^{2}$ & 6.54 & 1 & 6.54 & 0.18 & 0.6721 & \\
C $^{2}$ & 54.77 & 1 & 54.77 & 1.55 & 0.2285 & \\
D $^{2}$ & 193.91 & 1 & 193.91 & 5.48 & 0.0303 & \\
AB & 25.55 & 1 & 25.55 & 0.72 & 0.4060 & \\
AC & 19.27 & 1 & 19.27 & 0.54 & 0.4695 & \\
BD & 22.94 & 1 & 22.94 & 0.65 & 0.4306 & \\
Residual & 672.2 & 19 & 35.38 & & & \\
Lack of Fit & 636.9 & 15 & 42.46 & 4.81 & $\mathbf{0 . 0 6 9 9}$ & not significant \\
Pure Error & 35.3 & 4 & 8.82 & & & \\
Cor Total & 1548.48 & 29 & & & & \\
R-squared & 0.5639 & & & & &
\end{tabular}

this case, time $\left(\mathrm{A}^{2}\right)$ and enzyme to substrate concentration $\left(\mathrm{D}^{2}\right)$ are significant model terms.

3.6.2 Response surface plots and the effects of factors for antioxidant activity of snakehead protein hydrolysate (SPH)

According to the model regression analysis, the best explanatory model equation is as follows in terms of coded factors:

Antioxidant activity of snakehead protein hydrolysate $(\mathrm{SPH})=+22.36-1.75 \mathrm{~A}+1.44 \mathrm{C}+15.90 \mathrm{~A} 2-1.61 \mathrm{~B} 2-$ $4.65 \mathrm{C} 2-8.74 \mathrm{D} 2-1.26 \mathrm{AB}-1.10 \mathrm{AC}-1.20 \mathrm{BD}$.

Figure 1 (b) shows the response surface plot for SPH antioxidant activity as a function of temperature and time. The 3D surface graphs demonstrated that the antioxidant activity increased with the temperature increased until $65^{\circ} \mathrm{C}$ onwards. During hydrolysis, the breakdown of peptide bond allows the release of hydrophobic peptides which capable to inhibit free radicals and lipid peroxidation (Song et al., 2011). Hence, higher hydrolysis temperature leads to higher peptides breakdown, and thus more hydrophobic peptide molecules such as alanine, valine, leucine, isoleucine, phenylalanine and methionine available against free radicals of the 1,1- diphenyl-2-picrylhydrazyl (DPPH). This figure also demonstrates that hydrolysis time increased with SPH's DPPH scavenging activity, most likely due to increased peptide content in the supernatant. This finding was in contrast with Halim and Sarbon (2017) who reported a decreased DPPH scavenging activity from eel protein hydrolysate as hydrolysis time increased. This may due to the different molecular weight of protein between the snakehead and eel. Therefore different hydrolysis time is required. According to Chalamaiah et al. (2012), hydrolysis time affects proteolysis and results in varying peptide products with different DPPH scavenging capabilities.

\subsubsection{Optimization of yield and antioxidant activity of snakehead protein hydrolysate (SPH)}

\subsubsection{Optimum response conditions.}

The desirability profiles for the optimum condition suggested by RSM are shown in Table 5. The desirability value close to 1 showed that the suggested conditions were the most suitable in obtaining optimum SPH with high in antioxidant activity. Therefore, the suggested hydrolysis conditions for $\mathrm{SPH}$ were $154.26 \mathrm{mins}, 46.84^{\circ}$ $\mathrm{C}, \mathrm{pH} 8.46$, and enzyme concentration of $1.04 \%$. At these conditions, the predicted DPPH antioxidant activity was $15.29 \%$.

\subsection{Validation test}

Response Surface Methodology (RSM) has been used to optimize independent variables which affecting enzymatic protein hydrolysis and to study the relationship between hydrolysis conditions (time, temperature, $\mathrm{pH}$ and enzyme to substrate concentration) on the DPPH antioxidant activity of snakehead protein

Table 5. Solutions suggested for optimized conditions for snakehead protein hydrolysate

\begin{tabular}{cccccccc}
\hline Number & Time & Temperature & $\mathrm{pH}$ & Enzyme & DPPH & Desirability & \\
\hline 1 & $\underline{154.26}$ & $\underline{46.84}$ & $\underline{8.46}$ & $\underline{1.04}$ & $\underline{15.2937}$ & $\underline{1}$ & $\underline{\text { Selected }}$ \\
2 & 114.07 & 56.68 & 9.41 & 2.06 & 22.4756 & 1 & \\
3 & 149.44 & 59.87 & 8.29 & 1.61 & 20.5655 & 1 & \\
4 & 128.36 & 55.16 & 8.18 & 2.76 & 13.2505 & 1 & \\
5 & 85.38 & 59.38 & 8.82 & 2.96 & 19.5452 & 1 & \\
\hline
\end{tabular}


hydrolysate. To confirm the validity of the model, an experiment was conducted under optimal conditions, with three replicates for each response. The DPPH antioxidant activity obtained was $15.05 \%$ which was very close with the predicted value generated by RSM $(15.29 \%)(p>0.05)$. Since model validation showed a good agreement between experimental results and the predicted responses, RSM was successfully used to investigate the effects of time, temperature, $\mathrm{pH}$, and enzyme to substrate concentration on enzymatic hydrolysis in order to produce SPH with higher antioxidant activity.

\subsection{Antioxidant activity of optimized snakehead protein hydrolysate (SPH)}

\subsubsection{Chelating effects on ferrous ion}

The chelating effects of ferrous ions were used to determine the ability of hydrolysates in the metalchelating activity. Figure 2 shows chelating effects on ferrous ion activity of snakehead protein hydrolysate (SPH) at a concentration of $1 \mathrm{mg} / \mathrm{mL}$. The results indicated significant differences $(p<0.05)$ between the snakehead protein hydrolysate (SPH) and BHT. The SPH showed strong chelating activity (30.93\%) on ferrous ion compared to the positive control (BHT). The ability to form iron complexes is an important attribute in many foods as oxidative processes are strongly influenced by trace metal compounds, which are present in food (Sarbon et al., 2018). Similarly, the study presented by Hamid et al. (2015) also reported the golden apple snails' hydrolysate demonstrated stronger chelating effects than BHT. Hence, the results obtained indicate that metal chelating effects of the hydrolysate were able to retard the oxidation process. Thus, SPH may prevent metal ion-dependent oxidative damage to food lipids and thus serve as a food preservative.

\subsubsection{Hydroxyl radical scavenging activity}

Figure 2 shows a comparison of hydroxyl radical scavenging activity for snakehead protein hydrolysate and BHT at a concentration of $1 \mathrm{mg} / \mathrm{mL}$. The results show a significant difference $(\mathrm{p}<0.05)$ between BHT and snakehead protein hydrolysate (SPH). According to Sun et al. (2013), the hydroxyl radical is the most reactive free radical. It forms from a reaction between superoxide anion and hydrogen peroxide in the presence of a metallic ion catalyst such as copper or iron. The result obtained showed that the SPH exhibited a higher hydroxyl scavenging activity than the positive control, BHT. According to Rafi et al. (2015), these results are most likely due to the antioxidant activity of intrinsic SPH amino acids and peptide sequences, especially hydrophobic amino acids that react with peptide and fatty acids which inhibit oxidation. The hydroxyl radical scavenging activity of snakehead protein hydrolysate was higher $(75.71 \%)$ compared to hydrolysate from Alaska Pollack frame (35\%) (Je et al., 2005) but quite similar to hoki frame (81.39\%) (Kim et al., 2007). A study by Rabiei et al. (2019) also found that the hydroxyl radical scavenging activity of fish protein hydrolysate from Klunzinger's mullet (L. klunzingeri) muscle was higher than BHT. In conclusion, the snakeheads protein hydrolysate offers good hydroxyl radical scavenging activity for use in food products.

\subsubsection{DPPH radical scavenging activity}

At a concentration of $1 \mathrm{mg} / \mathrm{mL}$ for each solution tested, Figure 2 shows the percentage of DPPH radical scavenging activity for snakehead protein hydrolysate $(\mathrm{SPH})$ with BHT as the positive control. Significant differences $(p<0.05)$ were found between SPH and positive control (BHT), while BHT exhibited a higher percentage of DPPH radical inhibition than snakehead protein hydrolysate $(\mathrm{SPH})$. These findings are in agreement with those of Razali et al. (2015), who reported BHT presented the highest DPPH radical inhibition for all tested samples at different molecular weights $(10,5$ and $3 \mathrm{kDa})$. The results demonstrated that SPH contains hydrogen donors that react with free radicals, converting them to more stable products and thus terminating radical chain reactions. Nevertheless, BHT remains the better DPPH radical scavenger.

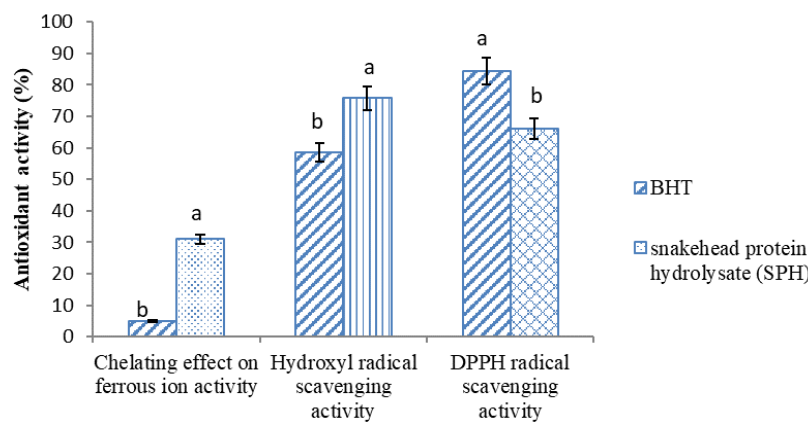

Figure 2. Chelating effect on ferrous ion, hydroxyl radical scavenging and DPPH radical scavenging of the snakehead protein hydrolysate (SPH) and positive control (BHT) at $1 \mathrm{mg} /$ $\mathrm{mL}$ concentrations. All the results are triplicate of mean $\pm \mathrm{SD}$. Different letters above the bars indicate the significant difference within groups $(\mathrm{p}<0.05)$

\section{Conclusion}

This study shows that snakehead protein has a high moisture content, relatively high protein, and low fat and ash content. The yield and antioxidant activity (DPPH) of snakehead protein hydrolysate were significantly influenced by time, temperature, $\mathrm{pH}$ and enzyme to substrate ratio. The suggested hydrolysis conditions for obtaining the optimum in yield and DPPH antioxidant 
activity using Alcalase ${ }^{\circledR}$ enzyme are a time of 154.26 mins, temperature of $46.84^{\circ} \mathrm{C}, \mathrm{pH}$ of 8.46 , and Alcalase ${ }^{\circledR}$ enzyme concentration of $1.04 \%$. Validation tests found that the antioxidant activity of snakehead protein hydrolysate (SPH) was close to the predicted values generated by RSM. The optimized SPH can be a potential for radical scavenging due to high percentage of hydroxyl radical scavenging activity and chelating effects of ferrous ions. Therefore, this hydrolysate may be exploited as a promising potential candidate for a natural antioxidant.

\section{References}

Ahmed, S., Arifur Rahman, A.F.M., Mustafa, M.G., Hossain, M.B. and Nahar, N. (2012). Nutrient composition of indigenous and exotic fishes of rainfed waterlogged paddy fields in Lakshmipur, Bangladesh. World Journal of Zoology, 7(2), 135140. https://doi:10.5829/idosi.wjz.2012.7.2.63162

AOAC. (2002). Official Methods of Analysis, $16^{\text {th }}$ ed. Washington DC, USA: Association of Official Analytical Chemists.

Canettieri, E.V., Rocha, G.J., Carvalho, J.A. and Silva, J.B. (2007). Optimization of acid hydrolysis from the hemicellulosic fraction of Eucalyptus grandis residue using response surface methodology. Bioresource Technology, 98(2), 422-428. https://doi: 10.1016/j.biortech.2005.12.012

Chalamaiah, M., Dinesh Kumar, B., Hemalatha, R. and Jyothirmayi, T. (2012). Fish protein hydrolysates: Proximate composition, amino acid composition, antioxidant activities and applications: A review. Food Chemistry, 135(4), 3020-3038. https://doi: 10.1016/j.foodchem.2012.06.100.

Ghassem, M., Babji, A.S., Said, M., Mahmoodani, F. and Arihara, A. (2014). Angiotensin I- Converting enzyme inhibitory peptides from snakehead fish sarcoplasmic protein hydroysate. Journal of Food Biochemistry, 38(2), 140-149. https:// doi.org/10.1111/jfbc.12031

Halim, N.R.A. and Sarbon, N.M. (2017). A response surface approach on hydrolysis condition of eel (Monopterus Sp.) protein hydrolysate with antioxidant activity. International Food Research Journal, 24(3), 1081-1093.

Hamid, S.A., Halim, N.R.A. and Sarbon, N.M. (2015). Optimization of enzymatic hydrolysis condition of golden apple snails (Ampuilariidae) hydrolysate on antioxidant activity by Alcalase. International Food Research Journal, 22(4), 1615-1622.

Haniffa, M.A. and Marimuthu, K. (2004). Seed production and culture of snakehead. INFOFISH
International, 2, 16-18.

Haslaniza, H., Maskat, M.Y., Wan Aida, W.M., Mamot, S. and Saadiah, I. (2013). Optimization of enzymatic hydrolysis of cockle (Anadara granosa) meat wash water precipitate for the development of seafood flavor. International Food Research Journal, 20(6), 3053-3059.

Herpendi, N., Huda, A., Rosma and Wan Nadiah, W.A. (2013). Optimizing the enzymatic hydrolysis of skipjack tuna (Katsuwonus pelamis) dark protein using Alcalase enzyme: A response surface approach. Journal of Fisheries and Aquatic Science, 8, 494-505. https://doi.org/10.3923/ jfas.2013.494.505

Ishak, N.H. and Sarbon, N.M. (2017). Optimization of the enzymatic hydrolysis conditions of waste from shortfin scad (Decapterus Macrosoma) for the production of angiotensin I- converting enzyme (ACE) inhibitory peptide using response surface methodology. International Food Research Journal, 24(4), 1735-1743.

Je, J.Y., Park, P.J. and Kim, S.K. (2005). Antioxidant activity of a peptide isolated from Alaska pollack (Theragra chalcogramma) frame protein hydrolysates. Food Research International, 38, 550. https://doi.org/10.1016/j.foodres.2004.07.005

Kang, P.Y., Ishak, NH. and Sarbon, N.M. (2018). Optimization of enzymatic hydrolysis of shortfin scad (Decapterus macrosoma) myofibrillar protein with antioxidant effect using Acalase. International Food Research Journal, 25(5), 1808-1817.

Kim, S.Y., Je, J.Y. and Kim, S.K. (2007). Purification and characterization of antioxidant peptide from hoki (Johnius belengerii) frame protein by gastrointestinal digestion. The Journal of Nutritional Biochemistry, 18(1), 31-38. https://doi.org/10.1016/ j.jnutbio.2006.02.006

Maache-Rezzoug, Z., Pierre, G., Nouviaire, A., Maugard, T. and Rezzoug, S.A. (2011). Optimizing thermomechanical pretreatment conditions to enhance enzymatic hydrolysis of wheat straw by response surface methodology. Biomass and Bioenergy, 35(7), 3129-3138. https:// doi.org/10.1016/j.biombioe.2011.04.012

Piggott, G.M. and Tucker, B.W. (1990). Effects of technology on nutrition. New York, USA: Marcel Dekker.

Quaglia, G.B. and Orban, E. (1990). Influence of enzymatic hydrolysis on structure and emulsifying properties of sardine (Sardina pilchardus) protein hydrolysates. Journal of Food Science, 55(6), 15711573.

https://doi.org/10.1111/j.1365- 


\subsection{0.tb03571.x}

Rafi, N.M., Halim, N.R.A., Amin, A.M. and Sarbon, N.M. (2015). Response surface optimization of enzymatic hydrolysis conditions of lead tree (Leucaena leucocephala) seed hydrolysate. International Food Research Journal, 22(3), 10151023.

Rabiei S., Rezaei, M., Asgharzade, S., Nikoo, M. and Rafieia-kopai, M. (2019). Antioxidant and cytotoxic properties of protein hydrolysates obtained from enzymatic hydrolysis of Klunzinger's mullet (Liza klunzingeri) muscle. Brazilian Journal of Pharmaceutical Sciences, 55, e18304. https:// doi.org/10.1590/s2175-97902019000218304

Razali, A.N., Amin, A.M. and Sarbon, N.M. (2015). Antioxidant activity and functional properties of fractionated cobia skin gelatin hydrolysate at different molecular weight. International Food Research Journal, 22(2), 651-660.

Sarbon, N.M., Badii, F. and Howell, N.K. (2018). Purification and characterization of antioxidative peptides derived from chicken skin gelatin hydrolysate. Food Hydrocolloids, 85, 311-320. https://doi.org/10.1016/j.foodhyd.2018.06.048

See, S.F., Hoo, L.L. and Babji, A.S. (2011). Optimization of enzymatic hydrolysis of salmon (Salmo salar) skin by Alcalase. International Food Research Journal, 18(4), 1359-1365.

Slizyte, R., Dauksas, E., Falch, E., Storro, I. and Rustad, T. (2005). Yield and composition of different fractions obtained after enzymatic hydrolysis of cod (Gadus morhua) by-products. Process Biochemistry, 40(3-4), 1415-1424. https://doi.org/10.1016/ j.procbio.2004.06.033

Song, R., Wei, R., Zhang, B., Yang, Z. and Wang, D. (2011). Antioxidant and antiproliferative activities of heated sterilized pepsin hydrolysate derived from half-fin anchovy. Marine Drugs, 9(6), 1142-1156. https://doi.org/10.3390/md9061142

Sun, L., Zhang, Y. and Zhuang, Y. (2013). Antiphotoaging effect and purification of an antioxidant peptide from tilapia (Oreochromis niloticus) gelatin peptides. Journal of Functional Foods, 5(1), 154-162. https://doi.org/10.1016/ j.jff.2012.09.006

Thiansilakul, Y., Benjakul, S. and Shahidi, F. (2007). Compositions, functional properties and antioxidative activity of protein hydrolysates prepared from round scad (Decapterus maruadsi). Food Chemistry, 103(4), 1385-1394. https:// doi.org/10.1016/j.foodchem.2006.10.055

Umayaparvathi, S., Meenakshi, S., Vimalraj, V.,
Arumugam, M., Sivagami, G. and Balasubramanian, T. (2014). Antioxidant activity and anticancer effect of bioactive peptide from enzymatic hydrolysate of oyster (Saccostrea cucullata). Biomedicine and Preventive Nutrition, 4(3), 243-253. https:// doi.org/10.1016/j.bionut.2014.04.006

Zuraini, A., Somchit, M.N., Solihah, M.H., Goh, Y.M., Arifah, A.K., Zakaria, M.S., Somchit, N., Rajion, M.A., Zakaria, Z.A. and Mat Jais, A.M. (2006). Fatty acid and amino acid composition of three local Malaysian Channa spp. Fish. Food Chemistry, 97(4), 674-678.

https://doi.org/10.1016/ 